\title{
Competitive Elections, Status Anxieties, and the Relative Strength of Ethnic versus National Identification in Africa
}

\author{
Elena Gadjanova ${ }^{1}[$
}

Accepted: 21 January 2021 / Published online: 5 February 2021

(c) The Author(s) 2021

\begin{abstract}
Research shows that ethnic identification increases on the eve of competitive elections in Africa, but does it do so at the expense of national solidarities? Do competitive elections exacerbate the negative expressions of strong ethnic attachmentscoethnic favoritism, relative status concerns, and social distance to other groups? These questions are important because the latter attitudes and perceptions are linked to a host of ills in democracies. In this paper, I examine how the proximity and competitiveness of national elections influence ingroup favoritism, ethnic groups' status anxieties, perceived discrimination, and trust in Sub-Saharan Africa. Drawing on six rounds of survey data for seventeen countries over 14 years, I find that national identities diminish in salience relative to ethnic ones as political competition increases, and that this is accompanied by heightened perceptions of ethnically-motivated discrimination, increased status anxieties, and lower levels of both inter-ethnic and generalized trust closer to nationally-competitive elections. Therefore, the electoral cycle strongly influences group anxieties in plural societies where political competition is high, and should be taken into account when designing measures to mitigate ethnic polarization in multi-ethnic states.
\end{abstract}

Keywords Ethnicity $\cdot$ Elections $\cdot$ Ethnic anxieties $\cdot$ Africa

Elena Gadjanova

e.gadjanova@exeter.ac.uk

1 Department of Politics, University of Exeter, Amory Building B.223, Exeter EX4 4RJ, UK 


\section{Introduction}

Strong ethnic attachments are often seen as undermining national projects. ${ }^{1} \mathrm{~A}$ large literature links ethnic identities with state fragmentation, often through violent secession (Cederman et al. 2010; Hale 2008; Sambanis 2001; Peterson 2002). Fostering national unity is a particular challenge for states in Sub-Saharan Africa because of their high ethno-linguistic diversity and the largely artificial colonial borders partitioning cohesive groups among multiple countries (Herbst 1989; Young 1979).

Instrumentalist theories of ethnicity posit that ethnic attachments persist because they are "useful" in extracting benefits from the state (Chandra 2007; Eifert et al. 2010; Ichino and Nathan 2013). Within the currently dominant constructivist understanding of identity formation, there is also a near consensus that ethnic identities are malleable, contingent, and situational (Chandra 2012). This has in turn led to expectations that ethnic identities should vary over time (Kuo and Margalit 2012) and would become more salient when access to states' resources is up for grabs, such as when national elections approach (Eifert et al. 2010).

Apart from being malleable and constructed, ethnic identities are also inherently social and relational. Research from various disciplines draws attention to the importance of group boundaries (Barth 1998; Wimmer 2013), ethnic communities' relative status and position vis-a-vis others (Blumer 1958; Horowitz 1985), and the ingroup favoritism/outgroup solidarity trade-off inherent in strong group attachments. The Social Psychology literature asserts that strong ethnic identities are invariably accompanied by ethnocentrism expressed as ingroup favoritism and hostility towards outgroups, and frequently manifesting as mistrust, prejudice, and perceived discrimination (Brewer 1981; LeVine and Campbell 1972; Tajfel 1982). Within these perspectives, the political salience of ethnic identities is itself a function of the strength of the boundaries groups create and maintain vis-a-vis each other (Wimmer 2008).

Does political competition lead to a decrease in the relative salience of national attachments in Sub-Saharan Africa? Does it also heighten group anxieties and diminish inter-ethnic trust? These questions are important because the relative strength of ethnic compared to national loyalties is an important indicator of social cohesion (Easterly et al. 2006; Maxwell 2009), and has implications for the way societies function overall (Collier 2011). Ethnocentrism is linked to entrenched inequality, stunted growth, preference polarization, and communal violence in new democracies (Easterly and Levine 1997; Horowitz 1985; Wilkinson 2005). The literature on civil wars establishes a direct link between ethnic fears and resentments and the severity of conflict (Bhavnani and Miodownik 2009) and shows that elections increase ethnic groups' likelihood of resorting to violence (Cederman et al. 2013). The same processes that heighten ethnic identification are expected to also cause

\footnotetext{
1 Data and replication materials for this paper are available from the Political Behavior Dataverse, https ://doi.org/10.7910/DVN/3DIDV7.
} 
shifts in pan-ethnic or cross-ethnic solidarities, and influence individuals' perceptions of relative group status and attitudes towards other groups.

Despite the centrality of these issues to governance and politics in Sub-Saharan Africa and beyond, studies of the effects of political competition on national identification and attitudes towards out-groups are rare and focus on individual countries only e.g. (Ichino and Nathan 2013; Kasara 2013; Michelitch 2015). The few existing comparative studies on ethnic and national identities in Africa do not allow for temporal variation in national identification in response to the political environment, largely because of data constraints (Robinson 2014). ${ }^{2}$

In this paper, I examine the effect of political competition on the relative salience of national versus ethnic identification in Sub-Saharan Africa and study the extent to which some of the negative attitudinal expressions of strong ethnic identities are also heightened as a result of political competition. In particular, I study whether proximity to closely-fought elections increases perceptions of ethnically-motivated discrimination, relative status concerns, and support for ingroup favoritism, and whether it lowers ethnic and generalized trust. Empirically, I utilize six rounds of Afrobarometer surveys for seventeen countries in Sub-Saharan Africa. This data allows for variation over time on a number of key measures of interest related to respondents' choice of ethnic or national identity, patronage attitudes, perceived discrimination, status anxieties, and ethnic and generalized trust.

I find that respondents are less likely to identify in national relative to ethnic terms close to competitive elections. Reduced national identification is accompanied by heightened perceptions of ethnically-motivated discrimination, increased relative status concerns, and lower levels of both inter-ethnic and generalized trust. Remarkably, all these accompanying anxieties worsen as competitive national elections approach. In contrast, I find little evidence that competition-driven ethnic identification is purely instrumental: respondents are not more likely to expect patronage from elected officials or condone ethnic favoritism closer to competitive elections. The nature of the data does not allow me to dismiss instrumental motivations behind ethnic identification and response bias remains a concern. However, it is likely that these instrumental motivations are accompanied by and expressed through strong affective responses. The results suggest that we require models of politics able to better integrate the affective and instrumental aspects of ethnic attachments in order to fully grasp the impact of the political environment on group solidarities.

The paper contributes to two distinct literatures. First, it speaks directly to findings by Eifert et al. (2010) on the effect of the proximity to competitive elections on the salience of ethnic identities in Africa. It advances these findings by deriving two channels, through which the political environment heightens ethnic identification, and testing for their observable implications. Which channel is at work matters a great deal because unlike purely instrumental ethnicity, anxiety or discriminationinduced ethnic identification is accompanied by rejection of common identities and institutions, and increased hostility towards out-groups. This in turn severely hinders

\footnotetext{
${ }^{2}$ For a notable exception, see Higashijima and Houle (2018).
} 
the development of the common sense of belonging seen as crucial for the success of plural societies.

The results show that competitive elections in Africa are accompanied by a much higher increase in ethnic grievances and relative status anxieties compared to landslide elections. Several distinct literatures from Sociology, Social Psychology, and Political Science posit a causal link between ethnic anxieties and increased ethnic identification. Therefore, it is plausible that ethnic identification is higher closer to competitive elections in Africa because the competitive campaign environment surrounding these contests exacerbates ethnic anxieties in ways that landslide elections just do not do.

The findings should not be interpreted as an argument against political competition, however. The results show that ethnic anxieties are more sensitive to the electoral cycle in countries where political competition is high than in countries with landslide elections: in the former, anxieties rise around elections, but fall midelection cycle; in the latter, ethnic anxieties are relatively higher but more stable throughout. Thus, in order to reap the benefits of democratization and increased political competition, measures intended to address ethnic grievances in plural societies should also take into account the timing of the electoral cycle and anticipate these fluctuations.

Second, the paper contributes to the literature on nationalism in Sub-Saharan Africa. In contrast to work treating national identification as relatively stable over the medium to short term, it shows that national identification fluctuates in relation to the electoral cycle. This finding brings research on nationalism in Sub-Saharan Africa in line with other work highlighting temporal variation in national self-identification in other parts of the world (Kuo and Margalit 2012).

\section{How Do Competitive Elections Affect the Relative Salience of National Versus Ethnic Identities?}

The existing literature puts forward two separate channels, through which the political context and campaign environment could affect the relative salience of national compared to ethnic identities in Africa. The first is instrumental and operates through the expectation of patronage (Bates 1983; Chandra 2007; Fearon 1999). ${ }^{3}$ Within this perspective, ethnic identities are seen as tools for accessing power and are thus most valuable around election times. In low information environments in particular, ethnic parties strengthen ethnic identities by using ethnicity to signal future redistribution (Posner 2005; Chandra 2007). Ethnic parties appeal to coethnics and coethnics support ethnic parties because of expectations regarding the distribution of resources. Electoral campaigns can activate this channel by reminding voters of what they stand to gain by supporting a (coethnic) candidate. Voters would in turn face incentives to signal their ethnic identities to candidates in the

\footnotetext{
${ }^{3}$ For more on the the different types of individual motivations behind ethnic voting, see Ferree (2006, 2010).
} 
expectation of future rewards. The closer the election, the more voters stand to either gain or lose, so the stronger the incentives to seek out information and signal ethnic belonging. Competitive elections are characterized by bigger campaign efforts reflected in higher spending and communication volumes (Trumm et al. 2017), have higher voter turnout (Franklin et al. 2004), and more informed voters overall (Giebler et al. 2017). Recent studies of campaign effects in Africa show that voters seek out and are influenced by political communication prior to elections (Weghorst and Lindberg 2013; Carlson 2015; Conroy-Krutz et al. 2016).

The second channel relates to the affective value of ethnic attachments and operates when groups are experiencing uncertainty and anxiety related to relative status concerns (Horowitz 1985). Attitudinally, this is expressed in perceptions of group danger or threat, ethnically-motivated discrimination or unfair treatment in the hands of a central government. The Social Psychology literature links such perceptions to heightened in-group favoritism and identification, accompanied by increased social distance to other groups (Bogardus 1928; Tajfel 1982). The "rejection-disidentification" model ties perceived discrimination to reduced national identification directly by viewing increased ethnic identification as a way individuals cope with discrimination (Jasinskaja-Lahti et al. 2009). Closely-fought election campaigns are more likely to feature negative campaign messages and attacks (Skaperdas and Grofman 1995; Harrington Jr and Hess 1996) and are shown to be more polarizing (Hansen and Kosiara-Pedersen 2017) so we can expect campaign rhetoric around close elections in particular to result in heightened group anxieties and perceived discrimination.

It is important to note that these two channels are not mutually exclusive and may operate in tandem: individuals concerned about access to resources may also experience fears of loss of status, concerns about lack of recognition, and feel emotional attachment to their ethnic identities. They echo the distinction between instrumental and value rationality originally made by Weber (1978). ${ }^{4}$ Scholars of nationalism and ethnic conflict convincingly argue that a combination of the two best explains ethnic and nationalist behavior (Varshney 2003). Thus, in the context of competitive elections, polarizing campaign rhetoric relying on discourses of discrimination, victimization, and threat can simultaneously increase expectations of favoritism and exacerbate individual perceptions of status anxiety (Iyengar et al. 2012).

Campaign narratives and tropes are shown to evoke pride, grievances, or contempt related to ethnic belonging by focusing on stories of discrimination, marginalization, unfair or unequal treatment, often in the hands of the central government (Gadjanova 2013). These "constructions of grievance" in turn legitimate violence and spur collective action in the name of common identities, even when conflicts have ostensibly material origins as with disputes over land or natural resources (Aspinall 2007; Boone 2011). Apart from direct exposure to campaign appeals, the polarized political environment surrounding contested elections in Sub-Saharan Africa can increase the relative salience of ethnic attachments indirectly: through

\footnotetext{
${ }^{4}$ I thank an anonymous reviewer for this point.
} 
(social) media and everyday social interactions, including instances of ethnicallymotivated discrimination and micro aggression (Burbidge 2014; Michelitch 2015).

In sum, the instrumental channel linking the political environment with ethnic identification suggests that ethnic identification should be accompanied with a set of attitudes and expectations regarding ethnic favoritism and the distribution of patronage. The affective channel would lead us to expect that perceived discrimination, status anxiety, and lower inter-ethnic trust accompany ethnic attachments. Examining the attitudinal corollaries of strong ethnic attachments is important because these attitudes and perceptions are shown to have real consequences for inter-group relations in plural societies. If strong ethnic identification is taken up as a means to withdraw from the state in response to perceived discrimination, we can expect much intransigence, unwillingness to compromise, decision-making deadlock, even violence. On the other hand, manipulating patronage attitudes and fostering expectations of ethnic favoritism among voters can create strong incentives for politicians to extract resources from the state in order to strategically funnel development. In the long run, this increases corruption, creates inequality, undermines state capacity, and reduces trust in institutions and the democratic process overall.

\section{Data and Methodology}

I employ Afrobarometer data collected during rounds 2-7 between 2004 and 2018 in the following countries: Benin, Botswana, Burkina Faso, Ghana, Kenya, Liberia, Malawi, Mali, Mozambique, Namibia, Nigeria, Senegal, South Africa, Tanzania, Uganda, Zambia, and Zimbabwe. The seventeen countries held regular elections and were surveyed more than once between 2004 and 2018. Multiple country samples over time allow me to use hierarchical models with both random and fixed effects and to hold constant a range of country and round-level factors that can affect respondents' ethnic or national identification and its accompanying attitudes and perceptions: countries' (precolonial) history, various institutions including degrees of centralization and the type of the executive, levels of diversity, colonial past, the nation-building legacy of leaders, levels of democracy, the presence of ethnic movements and parties, levels of economic development, and history of ethnic violence (Bossuroy 2008; Miguel and Posner 2006; Robinson 2014; Chandra 2007).

The variable on the national versus ethnic identity trade-off comes from responses to the question:

"Let us suppose that you had to choose between being a [Ghanaian/Kenyan/etc.] and being a [respondent's (ethnic) identity group]. Which of these two groups do you feel most strongly attached to?" 
The variable takes two values: 1 if respondents gave "national identity" as the identity they feel more or only attached to, 0 otherwise. ${ }^{5}$ It has several advantages, which makes it suitable for the purposes of this paper. As other research has noted (Robinson 2014), because it is relative, this measure is comparable across respondents and countries. It is also consistent with constructivist notions that individuals hold multiple identities simultaneously. Unlike absolute measures, the question can also capture the relative strength of ethnic attachments and is thus consistent with measures of ethnocentrism from Social Psychology.

I expect respondents' choice of national versus ethnic identity to be systematically related to a set of shifting attitudes and perceptions regarding ethnic favoritism and the distribution of patronage, relative status concerns, and social distance to other ethnic groups. ${ }^{6}$ The identity choice of respondent $i$ in country $c$ at a time $t$ $\left(E_{i c t}\right)$ can therefore be expressed as:

$$
E_{i c t}=\beta Y_{i c t}+\gamma X_{i c t}+\mu_{i c t}
$$

The situational and contingent part of respondents' relative attachment to national or group identity is captured in the vector $\beta$ decomposed into $\beta_{1}$ favoritism + $\beta_{2}$ statusanxiety $+\beta_{3}$ socialdistance.

The vector $X_{i c t}$ contains individual characteristics such as gender, age, place of residence, education, and employment status. Other research on Sub-Saharan Africa shows these are strong predictors of respondents' national identification (Robinson 2014). Media exposure and the level of public interest likely also influence the effect of the political environment on identity choice. I proxy media exposure by answers to questions about the frequency, with which respondents read newspapers, listen to the radio, or watch $\mathrm{TV}^{7}$ The level of public interest is gauged from responses to the question "How interested would you say you are in public affairs?", transformed into a scale ranging from 0 (not at all) to 2 (a lot).

Within this vector, I also include a measure of whether a respondent belongs to the majority or plurality group in each country and whether their ethnic group controls government. ${ }^{8}$ There are several reasons to expect ethnic relative to national attachments to have different attitudinal corollaries among pluralities versus minorities and among groups in power versus powerless or disenfranchised populations. Theories emphasizing the effect of group size on ethnic mobilization (Posner 2005)

\footnotetext{
5 Note that from Afrobarometer round 3 onwards, respondents were given the option of rating their ethnic and national identities as equal. Therefore, the data also includes an ethnic identity variable coded 0 if respondents identified with their national identities more or only, 1 if they identified equally with ethnic and national identity, and 2 if they identified with their ethnic identities more or only. See the Online Appendix for details on how this varies across countries and rounds.

6 In line with the Social Psychology literature, I refer to perceived discrimination and low levels of interethnic trust as "social distance".

7 Factor variable, Eigenvalue $=1.225, \mathrm{AIC}=6.000, \mathrm{BIC}=34.972$.

8 I use a measure of government control rather than inclusion for two reasons, one theoretical and one methodological: first, Africa's states often have broad coalition governments and a powerful centralized executive in the form of the presidency. Taking mere inclusion in government as signifying power would overstate some ethnic groups' true position. And second, the latter would provide very little variation on the variable because most ethnic groups are formally represented in coalition governments.
} 
expect that individuals would self-select into larger ethnic identities in order to form minimum winning coalitions with a view to extracting resources from the state. Thus, instrumental motivations and expectations of ethnic favoritism may be more prevalent among members of plurality groups.

Larger groups or groups controlling government may see national identification as a means to state resources, however: Wimmer (1997) has described politics in post-colonial societies as a struggle over "who owns the state", suggesting there may be a link between instrumental self-identification and national identity. In other words, members of the plurality groups may identify with their national identity more than minorities, and this may still be driven by expectations of patronage and favoritism. Thus, plurality/majority group status and being in power could confound the relationship between patronage expectations and ethnic identification. Further, research on minority mobilization in other parts of the world shows that minorities experience more status anxiety and perceived discrimination than majorities, so should be more prone to grievance-based national dis-identification, particularly when not in power (Barreto and Pedraza 2009).

Finally, I also control for whether respondents are ruling party supporters in line with studies showing that this mediates attitudes towards democracy and government institutions in new democracies (Moehler 2009; Curini et al. 2012).

$\mu_{i} c t$ contains idiosyncratic levels of ethnic or national attachments that cannot be directly observed.

I then proceed to examine the extent to which the part of ethnic attachments determined by attitudes to patronage or group anxieties $Y_{i c t}$ is itself a function of the political environment (2).

$$
Y_{i c t}=\gamma X_{i c t}+\delta Z_{c t}+v_{i c t}
$$

The vector $Z_{c t}$ contains country-level factors, of which the proximity and competitiveness of the presidential election are the key predictors of interest. Presidential elections are arguably the most consequential political events in Sub-Saharan Africa because of the highly centralized nature of power and government authority (Posner and Young 2007). ${ }^{9}$

Following Eifert et al. (2010), I define proximity as - 1 times the absolute number of months between the day the survey was administered and the closest presidential election, and competitiveness as -1 times the difference in the percentage vote share between the winner and the runner up. For analytical purposes, I divide elections into three categories: (1) competitive: those with a margin of victory of less than $10 \%$, (2) less competitive: those with a margin of victory between 10 and $31 \%$, and (3) landslides: those with a margin of victory of over $31 \%$.

I divide competitiveness into three distinct categories for the following reasons: first, it is not reasonable to expect that a unit change in competitiveness (in this case $1 \%$ ) has a linear and cumulative effect on voter behavior. Electoral contests

\footnotetext{
${ }^{9}$ In the majority of cases, national-level elections were general, i.e. presidential and parliamentary elections were concurrent.
} 
Table 1 Characteristics of the sample

\begin{tabular}{|c|c|c|c|c|c|c|c|}
\hline \multirow[t]{2}{*}{ Country } & \multicolumn{3}{|c|}{ Electoral margin of victory } & \multicolumn{2}{|c|}{$\begin{array}{l}\text { Months to elec- } \\
\text { tion }\end{array}$} & \multirow[t]{2}{*}{ Total } & \multirow[t]{2}{*}{ Rounds } \\
\hline & Over $31 \%$ & $10-31 \%$ & Less than $10 \%$ & Min & $\operatorname{Max}$ & & \\
\hline Benin & 0 & 5998 & 0 & -28 & -8 & 5998 & $3-7$ \\
\hline Botswana & 1200 & 5998 & 0 & -28 & -3 & 7198 & $2-7$ \\
\hline Burkina Faso & 2400 & 2400 & 0 & -26 & -7 & 4800 & $4-7$ \\
\hline Ghana & 0 & 0 & 10,797 & -21 & -3 & 10,797 & $2-7$ \\
\hline Kenya & 0 & 3676 & 7499 & -21 & -2 & 11,175 & $2-7$ \\
\hline Liberia & 0 & 4798 & 0 & -35 & -9 & 4798 & $4-7$ \\
\hline Malawi & 1200 & 0 & 8407 & -29 & -1 & 9607 & $2-7$ \\
\hline Mali & 6076 & 0 & 1283 & -23 & -6 & 7359 & $2-7$ \\
\hline Mozambique & 6190 & 4800 & 0 & -28 & -6 & 10,990 & $2-7$ \\
\hline Namibia & 5999 & 1200 & 0 & -25 & -2 & 7199 & $2-7$ \\
\hline Nigeria & 4687 & 6428 & 2400 & -22 & -2 & 13,515 & $2-7$ \\
\hline Senegal & 4800 & 1200 & 1200 & -34 & -12 & 7200 & $2-7$ \\
\hline South Africa & 13,829 & 0 & 0 & -31 & -5 & 13,829 & $2-7$ \\
\hline Tanzania & 6135 & 4786 & 0 & -30 & -4 & 10,921 & $2-7$ \\
\hline Uganda & 5456 & 7775 & 0 & -30 & -9 & 13,231 & $2-7$ \\
\hline Zambia & 0 & 1200 & 5997 & -17 & -3 & 7197 & $2-7$ \\
\hline Zimbabwe & 0 & 5904 & 3448 & -30 & -1 & 9352 & $2-7$ \\
\hline Total & 57,972 & 56,163 & 41,031 & & & 155,166 & \\
\hline
\end{tabular}

perceived to be competitive are more likely to be behaviorally significant instead and a margin of victory of $10 \%$ or less is a commonly-cited measure of highly competitive elections. Prior to elections, citizens are unlikely to know the exact margin of victory, but will likely have expectations based on information acquired from a variety of sources: the media, the campaigns themselves, opinion polls (a central feature of African elections since the early 2000s), and from citizens' knowledge of past contests or down-ballot races. These assessments will not be precise, but will fall into broader competitiveness categories often delineated using horse-race reporting tropes such as "neck-and-neck", "close", "X candidate or party leading in polls", or "Y candidate or party leading by a large margin/heading for a landslide".

While the literature is less clear on what constitutes a landslide victory, common measures include margins of victory over $20 \%$ or winning $60 \%$ of the popular vote. The $31 \%$ cut-off adopted here corresponds to $60 \%$ of the popular vote or over and is useful because it splits the sample of non-competitive elections evenly thus providing sufficient power to examine the effect of large changes in competitiveness at the lower ends of the competitiveness measure (Table 1) ${ }^{10}$ Robustness checks show that results are not an artefact of the cut-off points used and are robust to a different cutoff and a linear competitiveness measure (see the Online Appendix).

$\overline{10}$ For example from -42 to -21 in Uganda or from -65 to -27 in Namibia. 


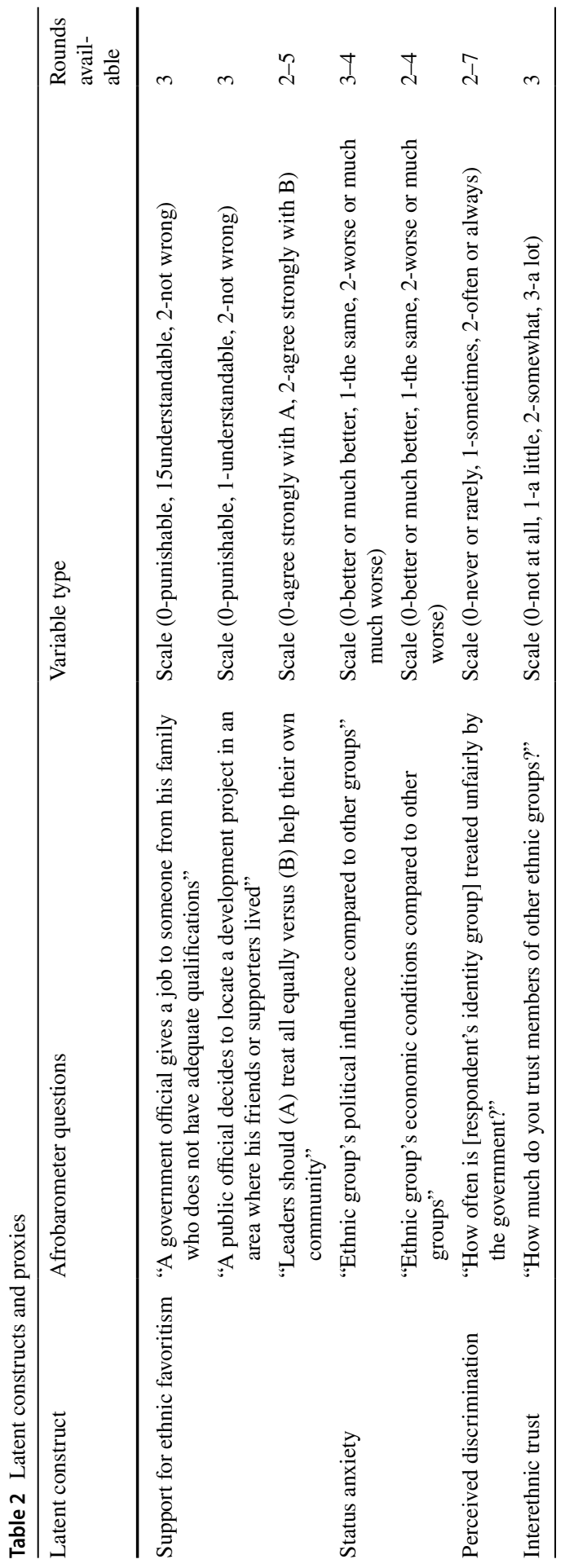


I also include an interaction term between proximity and competitiveness to allow for the change in attitudes and perceptions to depend on the competitiveness of the race as elections approach. I allow the vector $\gamma X_{i c t}$ containing individual covariates to also influence how the political environment affects individual attitudes towards ethnic patronage or social distance to other groups.

Eight of the seventeen countries in the sample had competitive elections, and 11 had landslides (Table 1 ). The majority (13 countries) had both competitive and noncompetitive elections. This within-country variation provides leverage for estimating the effects of the interaction between proximity and competitiveness on ethnic identification and its attitudinal corollaries.

The questions used to capture respondents' support for ethnic favoritism, status anxiety, perceived discrimination, and inter-ethnic trust are summarized in Table 2. The intuition behind the favoritism measures is that respondents who expect patronage from elected officials would be more likely to deem these practices "not wrong at all" or "wrong but understandable". Research on electoral clientelism in SubSaharan Africa shows that voters openly expect and demand patronage from candidates during the election campaigns, particularly in rural areas (Nugent 2001; Gadjanova 2017). Further, exposure to the competitive campaign environment where cash and other electoral "goodies" are frequently disbursed could affect attitudinal change along this dimension by making ethnic favoritism more acceptable overall.

Response bias is a particular concern with the first two favoritism questions. Political campaigns and media coverage may sensitize individuals by exposing patronage practices so respondents may instead understate their own support for the distribution of patronage by politicians as elections approach. Such a boomerang effect could be conditional on media exposure, education, and the level of the individual's public involvement and could manifest as differences between urban and rural voters, for example. I take a number of steps to minimize this bias (as detailed in Sect. 4 below). The third favoritism question should be less subject to social desirability bias, however, and would thus more likely reflect general perceptions regarding the distribution of patronage in respondents' immediate environments.

The Social Psychology literature highlights the centrality of negative group comparisons and individual perceptions of social position to status anxiety (Brewer 1981; Sherif et al. 1961). In line with this literature, I take respondents' rating of their ethnic groups' economic conditions and political influence as "worse" or "much worse" as indicative of high status anxiety. Perceived discrimination is captured by responses to the question "How often is [respondent's identity group] treated unfairly by the government?" and inter-ethnic trust by responses to the question "How much do you trust members of other ethnic groups?".

The analysis proceeds in three steps. First, I test whether proximity to competitive elections reduces national identification. Second, I examine whether expectations of ethnic favoritism, status anxieties, perceived discrimination, and (low) interethnic trust predict respondents' choice of ethnic over national identity. And third, I look for the impact of proximity to competitive elections on the latter attitudes and perceptions. 
Table 3 Competitive elections and national identification

\begin{tabular}{|c|c|c|c|c|}
\hline & $\begin{array}{l}\text { Model } 1 \text { Logit } \\
\text { National id. }\end{array}$ & $\begin{array}{l}\text { Model } 2 \text { Logit } \\
\text { National id. }\end{array}$ & $\begin{array}{l}\text { Model } 3 \text { Ordinal } \\
\text { logit National id. }\end{array}$ & $\begin{array}{l}\text { Model } 4 \text { OLS } \\
\text { National id. } \\
\text { scale }\end{array}$ \\
\hline Proximity to election & $0.008 * * *$ & $0.009 * * *$ & $0.009 * * *$ & $0.003 * * *$ \\
\hline \multicolumn{5}{|l|}{ Compet. scale } \\
\hline Margin $>31 \%$ & (Base) & (Base) & (Base) & (Base) \\
\hline Margin $10 \%-31 \%$ & -0.051 & $0.137 * * *$ & 0.022 & 0.001 \\
\hline Margin $<10 \%$ & $-0.194 * * *$ & 0.066 & 0.052 & 0.016 \\
\hline \multicolumn{5}{|l|}{ Proximity*Compet. scale } \\
\hline Margin $>31 \%$ & (Base) & (Base) & (Base) & (Base) \\
\hline $10 \%-31 \%$ & $0.005 * * *$ & $0.006 * * *$ & -0.001 & -0.000 \\
\hline Margin $<10 \%$ & $-0.009 * * *$ & $-0.019 * * *$ & $-0.012 * * *$ & $-0.004 * * *$ \\
\hline $\mathrm{N}$ & 144,190 & 95,553 & 127,770 & 127,770 \\
\hline Wald Chi2 & 3670.85 & 878.82 & 873.82 & 1411.57 \\
\hline Individual covariates & No & Yes & No & No \\
\hline Social des. bias controls & Yes & Yes & Yes & Yes \\
\hline
\end{tabular}

Note: In models 1-2, national identity is coded 1 if respondents reported they were more or only attached to their national identity, 0 otherwise. Models 3-4 report results for national identity from an ordinal logit model, in which the dependent variable is a scale (0-ethnic identity more or only, 1-ethnic and national identity equal, 2-national identity more or only). Models 1-3 are mixed (hierarchical) logit models with observations clustered within countries. Columns 1-3 report logit coefficients. Model 4 is a random effects linear model and column 4 reports OLS coefficients. All models include round fixed effects, time trends, and are weighted 1/total number of respondents per country. All models are also robust to including country fixed effects. The Online Appendix shows additional model specifications.

$* * * \mathrm{p}<0.01, * * \mathrm{p}<0.05, * \mathrm{p}<0.1$

To estimate Eqs. (1) and (2), I specify a number of mixed effects logit models with random intercepts for countries. ${ }^{11}$ As robustness checks, I re-estimate the models using mixed effects ordinal logit and OLS (see Sects. 4 and 5 below), as well as a series of logit models with country fixed effects (in the Online Appendix). All models include round fixed effects, time trend controls, and frequency weights. ${ }^{12}$

\footnotetext{
11 Mixed effects logit models (also known as hierarchical or multilevel logit models) are appropriate when data are clustered, as is the case here: individual respondents are clustered within countries and multiple surveys exist per country (McCulloch and Neuhaus 2005; Rabe-Hesketh and Skrondal 2008). Because random effects models are specifically intended to account for group-level (cluster) correlation among observations, Gelman and Hill (2006) recommend to "always use multilevel modeling (random effects)" for hierarchical data and show that these models outperform alternatives in estimates of vote choice using state-level opinion polling in the United States (Gelman and Hill 2006: 301-321).

12 Time trend variables are used in time series regressions to account for those unobservable variables influencing the dependent variable, which are highly-correlated with time (Wooldridge 2016). At the state level, these can be regime trends (democratization or autocratization), economic development, party institutionalization, etc., at the individual level they can capture gradual changes in voter preferences, for example. Each observation is weighted as $1 /$ total number of survey responses from the same country.
} 

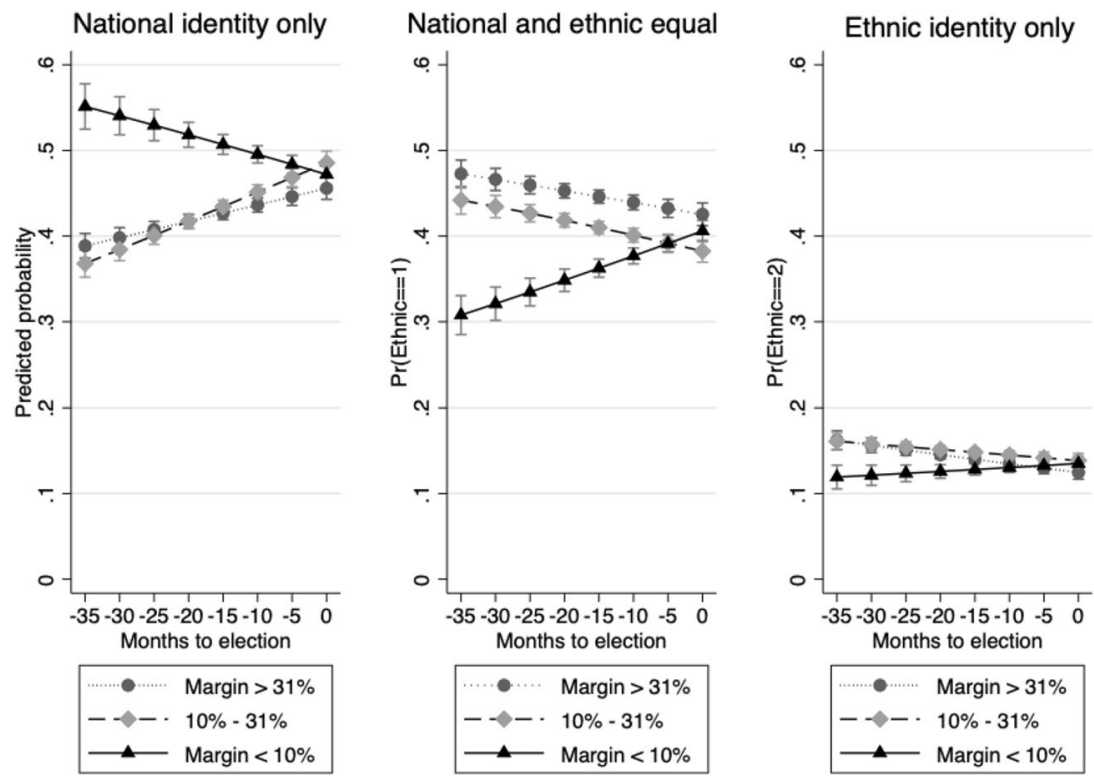

Fig. 1 Competitive elections and national versus ethnic identification. Note Predicted probabilities with 95 CI. All covariates held at their means

\section{Does Political Competition Reduce National Identification in Africa?}

Before I turn to the attitudinal corollaries of strong ethnic attachments and their political determinants, I briefly examine the effect of the political environment on the relative strength of ethnic and national identification in Sub-Saharan Africa. I test whether proximity to competitive elections makes respondents less likely to identify in national relative to ethnic terms.

The estimates show that proximity to competitive elections reduces national identification in Sub-Saharan Africa. The results are robust to different model specifications, round and country fixed effects, a host of individual covariates, and social desirability bias controls (Table 3, see the Online Appendix for additional specifications). The interaction term of the temporal proximity to elections and electoral competitiveness is illustrated in Fig. 1, where I juxtapose the effect of proximity on ethnic identification for competitive elections (those with a margin of victory of less than 10 victory above 10 above 31 .

There is a 10identity over the range of the proximity variable for competitive elections (equivalent to close to a 0.5 accompanied with a 5 respondents will identify with their ethnic identities only. For elections where the vote difference was above 10to the election date actually increases national relative to ethnic identification, Table 3).

These results are in line with empirical findings on the salience of ethnic identities using previous Afrobarometer rounds (Eifert et al. 2010). Further, they 
Table 4 Attitudes and perceptions accompanying strong ethnic attachments in Africa

\begin{tabular}{llllll}
\hline & Model 1 & Model 2 & Model 3 & Model 4 & Model 5 \\
\hline Leaders should help own community & $0.007 * * *$ & $0.003^{* *}$ & 0.002 & & 0.002 \\
Jobs for relatives & & & 0.006 & & 0.003 \\
Development for supporters & & & 0.006 & & 0.004 \\
Perceived discrimination & $0.052^{* * *}$ & $0.050^{* * *}$ & & $0.046^{* * *}$ & $0.046^{* * *}$ \\
Economic anxieties & & & & $0.008^{* *}$ & $0.008^{* *}$ \\
Political anxieties & & & 0.003 & 0.003 \\
Ethnic trust & & & & -0.003 & -0.004 \\
N & 81,957 & 62,995 & 17,358 & 16,260 & 15,590 \\
Wald Chi2 & 4974.00 & 1728.31 & 328.60 & 455.63 & 434.15 \\
Individual covariates & No & Yes & Yes & Yes & Yes \\
Social des. bias controls & No & Yes & Yes & Yes & Yes \\
\hline
\end{tabular}

Note Mixed (hierarchical) logit models with observations clustered within countries. Marginal effects $(\mathrm{dy} / \mathrm{dx})$ reported. All models include round fixed effects, time trends, and are weighted 1/total number of respondents per country.

$* * * \mathrm{p}<0.01, * * \mathrm{p}<0.05, * \mathrm{p}<0.1$. Additional specifications in the Online Appendix

suggest that like ethnic identities, national attachments in Africa are not static, but depend on the political context. The electoral cycle matters, as does the overall competitiveness of the race. The majority of the reduction in the relative salience of national identities is channelled in ethnic and national identities being seen as equal. There is, however, a concurrent increase in individuals identifying exclusively in ethnic terms close to competitive elections. One way to gain insight into the mechanisms underlying these shifts in relative identification is to examine what attitudes and perceptions accompany individuals' choice of ethnic over national identity. I turn to this question in the section below.

\section{What Attitudes and Perceptions Accompany Strong Ethnic Attachments in Africa?}

The literature on the link between ethnic identification and competitive elections suggests two sets of corollaries to strong ethnic attachments: those related to expectations of ethnic favoritism, and those related to relative status concerns and increased social distance to other ethnic groups. Table 4 lists the results from a series of logit models of the attitudinal determinants of strong ethnic attachments. ${ }^{13}$

I find that support for ethnic favoritism, perceived discrimination, and status anxieties are all associated with respondents' choice of ethnic identities at the expense of

\footnotetext{
13 Coded 1 if Afrobarometer respondents identified with their ethnic group "more" or "only", 0 otherwise.
} 
Table 5 Competitive elections and perceived discrimination

\begin{tabular}{|c|c|c|c|c|}
\hline & Model 1 logit & Model 2 logit & $\begin{array}{l}\text { Model } 3 \text { multino- } \\
\text { mial logit }\end{array}$ & Model 4 OLS \\
\hline Proximity & $0.001 * * *$ & $0.003 * *$ & 0.001 & $0.001 * *$ \\
\hline \multicolumn{5}{|l|}{ Compet. scale } \\
\hline Margin $>31 \%$ & (Base) & (Base) & (Base) & (Base) \\
\hline$=$ Margin $10-31 \%$ & $-0.296 * * *$ & $-0.274 * * *$ & $-0.255^{* * *}$ & $-0.108 * * *$ \\
\hline Margin $<10 \%$ & $-0.065^{*}$ & $-0.116^{* * *}$ & -0.070 & -0.008 \\
\hline \multicolumn{5}{|l|}{ Proximity $\times$ Compet. scale } \\
\hline Margin $>31 \%$ & (Base) & (Base) & (Base) & (Base) \\
\hline $10-31 \%$ & $-0.004 * *$ & $-0.004 *$ & $-0.004 *$ & $-0.002 * * *$ \\
\hline Margin $<10 \%$ & $0.011^{* * *}$ & $0.007 * * *$ & $0.012 * * *$ & $0.003 * * *$ \\
\hline $\mathrm{N}$ & 138,836 & 130,113 & 130,113 & 138,836 \\
\hline Wald or LR Chi2 & 6005.09 & 7626.33 & 25595.98 & 5478.21 \\
\hline Individual covariates & No & Yes & Yes & No \\
\hline Social des. bias controls & Yes & Yes & Yes & Yes \\
\hline
\end{tabular}

Note: In models 1 and 2, the dependent variable is coded 1 if respondents reported their ethnic group was "sometimes" or "often" discriminated against, 0 otherwise. In Models 3-4, the dependent variable is the perceived discrimination scale described in Table 2. Models 1-2 are mixed (hierarchical) logit models with observations clustered within countries. Model 3 is a multinomial logit model with country fixed effects, the coefficients reported are for "ethnic group sometimes treated unfairly" against the base "ethnic group never treated unfairly". Model 4 is a random effects linear model. Columns 1-3 report logit coefficients and column 4 reports OLS coefficients. All models include round fixed effects, time trends, and are weighted $1 /$ total number of respondents per country. Models 1,2 , and 4 are robust to including country fixed effects. The Online Appendix shows additional specifications.

$* * * p<0.01, * * p<0.05, * p<0.1$

national ones (Table 4). The affective variables (perceived discrimination and relative status anxieties in particular) are overall stronger and more robust.

It is possible that the questions related to patronage are subject to more response bias than questions regarding ethnic groups' relative status and perceived discrimination, suppressing the magnitude of the instrumental attitudes. While such bias cannot be completely ruled out, I address it in two additional ways. First, I identify a set of questions, which should be subject to similar bias, drop observations suspect of bias on these questions, and re-estimate the models using the remaining observations. Second, I re-run all models using coethnic interviewers only, expecting either that respondents would be more willing to admit their true attitudes regarding patronage when facing coethnics, or that facing coethnics would result in respondents' privileging co-ethnic favoritism (Habyarimana et al. 2009). The Online Appendix lists results of estimations keeping only respondents who admitted to paying a bribe for a document or permit and those interviewed by a coethnic. The main results reported in Table 4 do not change with the introduction of these additional checks.

Members of plurality/majority groups, groups controlling government, and ruling party supporters are all significantly less likely to privilege their ethnic 


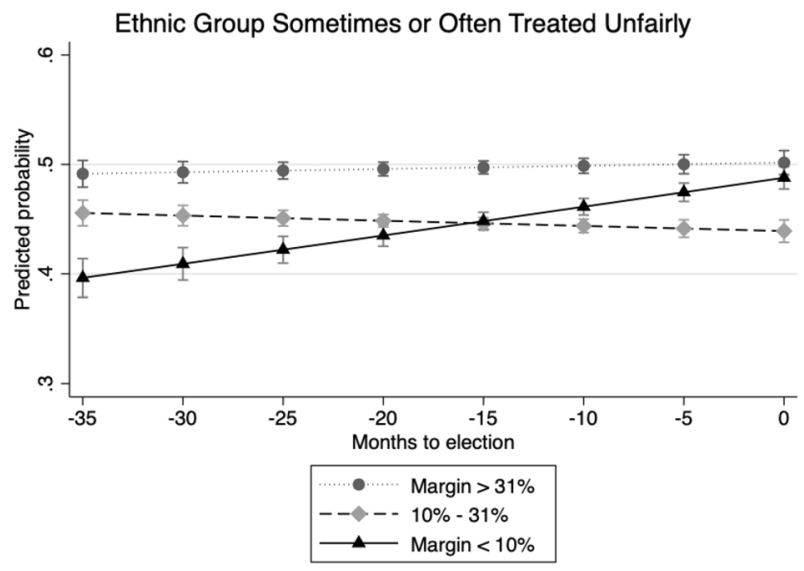

Fig. 2 Competitive elections and perceived discrimination. Note Predicted probabilities with 95 held at their means. The Online Appendix shows the results also hold for an alternative measure of perceived discrimination

relative to their national identities across model specifications (in the Online Appendix). This result contradicts expectations that larger groups would identify in ethnic terms prior to competitive elections in order to form minimum winning coalitions, but is in line with two theories of the relationship between group size and the choice between ethnic and national identification: the "state ownership" theory expecting larger groups and particularly those in power to be more likely to identify in national terms because they perceive themselves as controlling the state, and the "rejection-disidentification" model suggesting that ethnic identification is taken up as a defensive reaction to powerlessness and minority status in plural societies.

In sum, strong ethnic relative to national identification in Sub-Saharan Africa is accompanied by a host of group anxieties. The literature from Sociology and Social Psychology briefly reviewed above posits a direct causal link between relative status concerns, perceived discrimination, and an increase in ethnic identification. The heated campaign environment around competitive elections in Sub-Saharan Africa could also exacerbate relative status concerns and increase individual perceptions of ethnically-motivated discrimination resulting in worsening group anxieties as competitive elections approach.

\section{Competitive Elections, Perceived Discrimination, and Relative Status Anxieties in Africa}

I proceed to examine how the timing and competitiveness of elections influence the affective variables associated with strong ethnic relative to national attachments. Estimates for the effects of political competition on perceived discriminationthe strongest predictor of respondents' probability of identifying with their ethnic group rather than the common state-are shown in Table 5. I find that proximity 

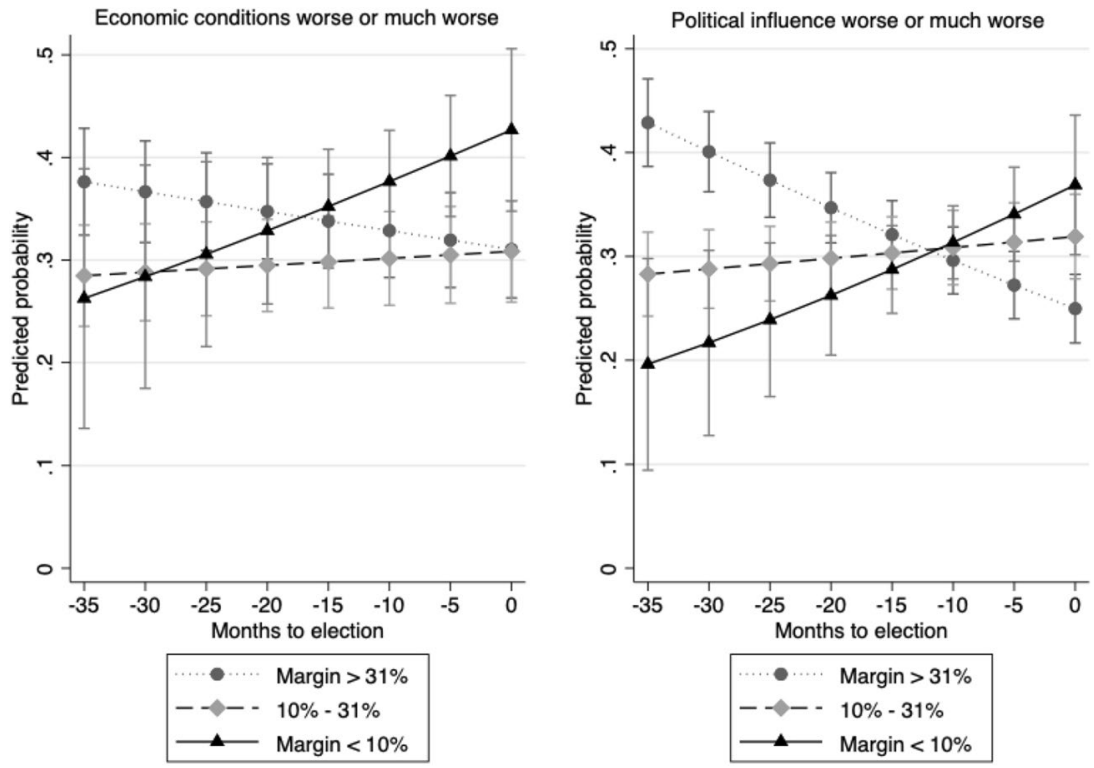

Fig. 3 Competitive elections and relative status anxieties. Note Predicted probabilities with 95 intervals. All covariates held at their means. Detailed results tables and additional specifications in the Online Appendix
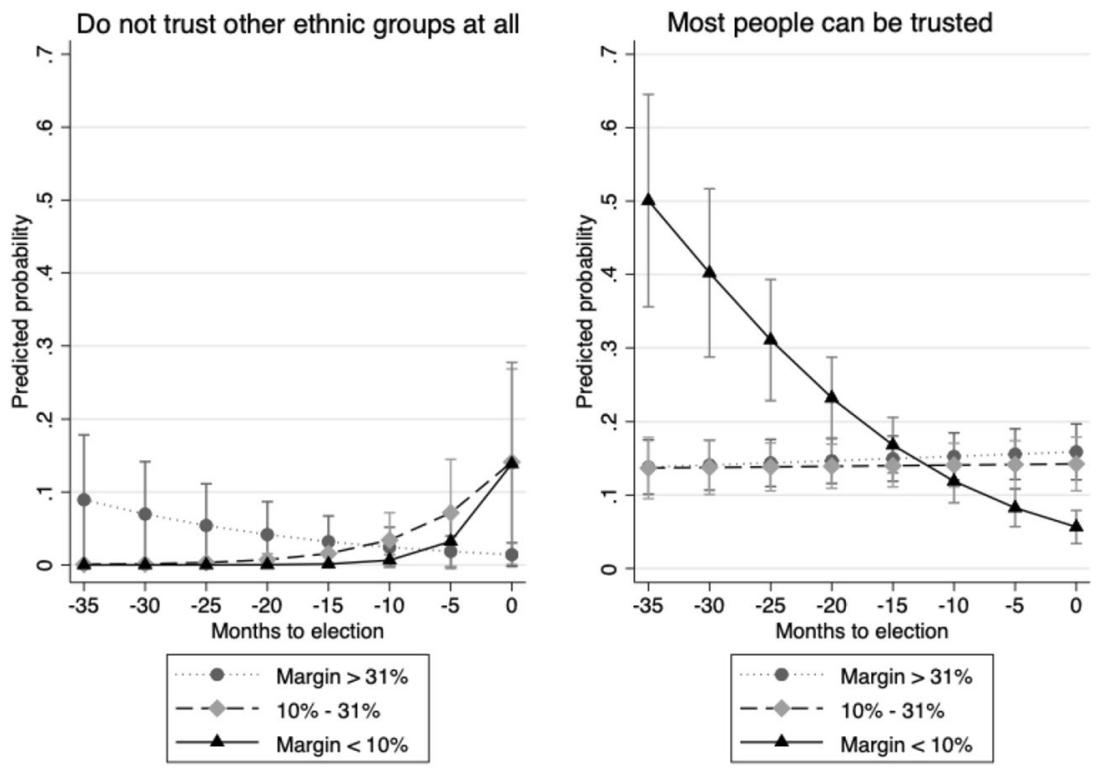

Fig. 4 Competitive elections and ethnic and generalized Trust. Note Predicted probabilities with 95intervals. All covariates held at their means. Detailed results tables and additional specifications in the Online Appendix 

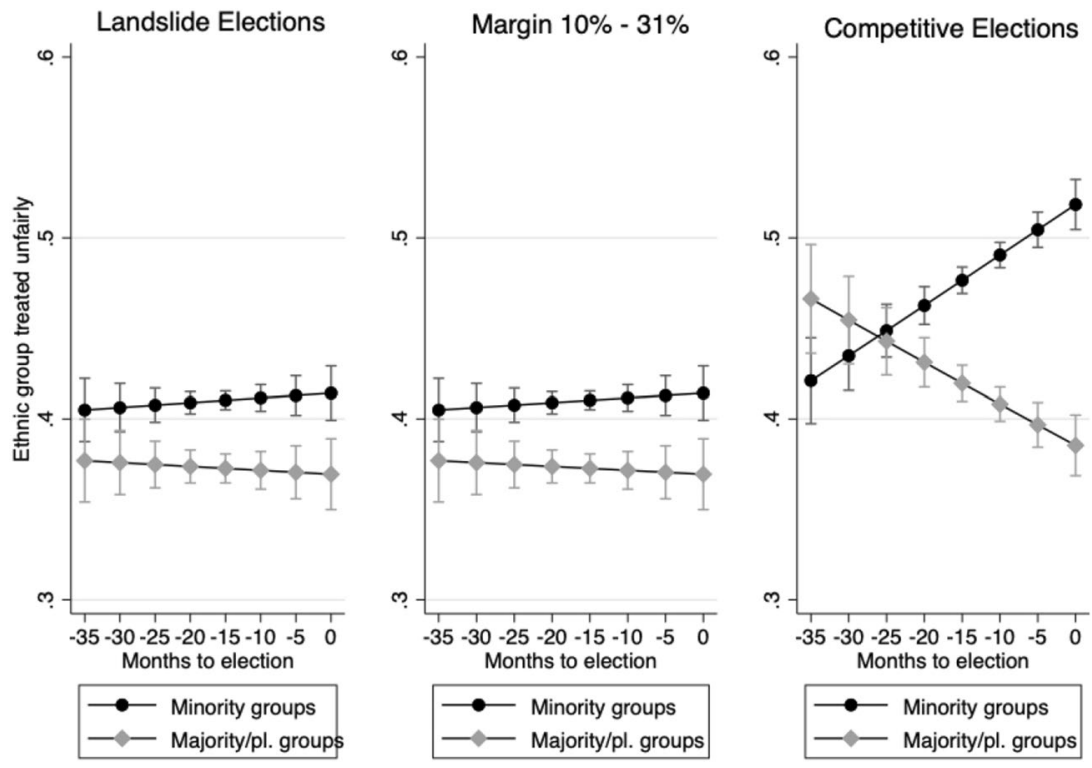

Fig. 5 Perceived discrimination by competitiveness and ethnic group size. Note Predicted probabilities with 95intervals. All covariates held at their means. Detailed results tables and additional specifications in the Online Appendix

to competitive elections significantly increases the likelihood that respondents will deem their ethnic group as being treated unfairly by the central government. The effect of proximity is conditional on the competitiveness of the race and the interaction is illustrated in Fig. 2.

For competitive elections (those with a margin of victory of less than 10perception of ethnically-motivated discrimination close to the election date. The predicted probability that respondents will deem their ethnic group as treated unfairly by the central government increases at a rate of approximately 0.5 closer to a presidential election. ${ }^{14}$ Because perceived discrimination is an important measure of social cohesion and is shown to affect other attitudes such as respondents' overall support for democracy, its fluctuation related to elections is a source of concern in African democracies.

I also trace the effect of the proximity to presidential elections and their competitiveness on individuals' relative status anxieties. I find a strong and substantively large effect of proximity to competitive elections on respondents' relative status concerns (Fig. 3). The probability that respondents would see their ethnic groups' economic conditions and political influence as "worse" or "much worse" than those of other ethnic groups increases at a rate of almost 1elections.

\footnotetext{
14 The results are robust to controlling for whether the election date was in the future (approaching) or in the past (in the Online Appendix).
} 

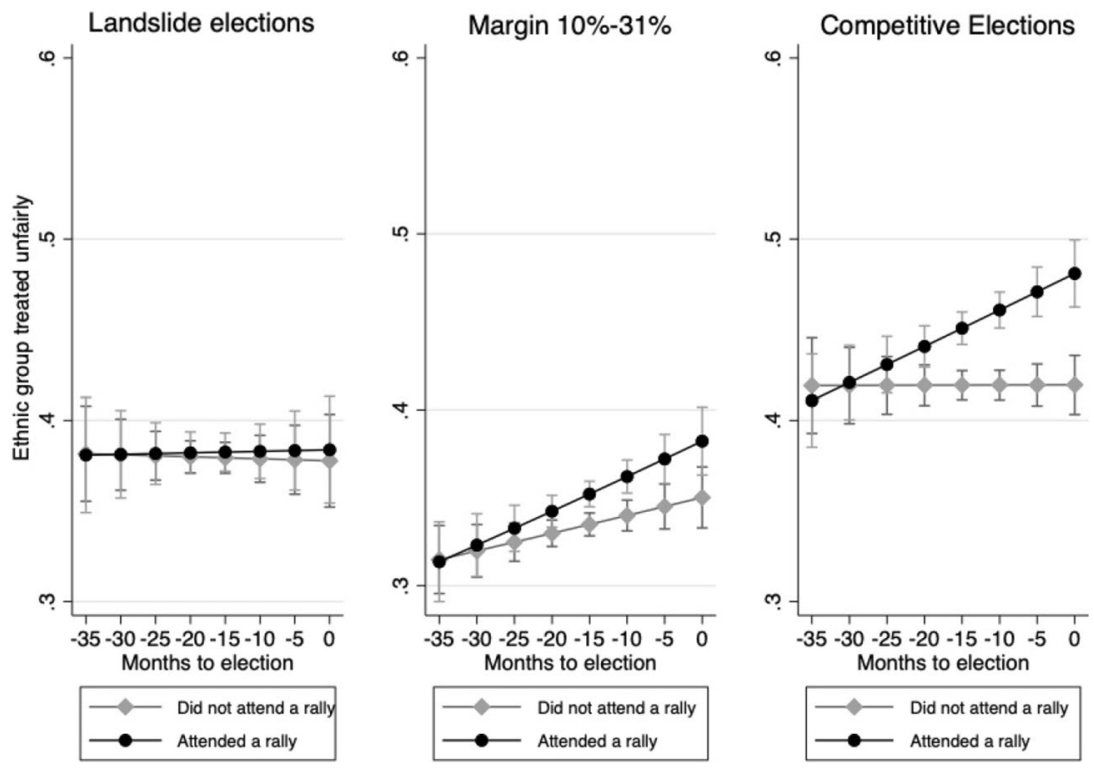

Fig. 6 Perceived discrimination by competitiveness and rally attendance. Note Predicted probabilities with 95 intervals. All covariates held at their means. Detailed results tables and additional specifications in the Online Appendix

Finally, Fig. 4 shows the effect proximity to national-level elections has on interethnic and generalized trust at different levels of electoral competitiveness. ${ }^{15}$ Outside of landslide elections, the predicted probability of a respondent saying they do not trust members of other ethnic groups at all increases by close to 20, with most of the increase taking place during the twelve months closest to the election. A word of caution regarding the ethnic trust estimates is due: Afrobarometer data on levels of inter-ethnic trust is only available for Round 3 (2005-2006). The results are thus based on a smaller sample, there is no within-country variation on the proximity variable, and estimates are driven by competitive races in Ghana, Kenya, and Malawi only. The generalized trust measure is available in both Rounds 3 and 5, improving the estimates' precision and confidence in the results. Fig. 4, right panel, shows that there is also a sharp drop in levels of generalized trust closer to presidential elections, and that this effect is limited to competitive elections only. Levels of generalized trust closer to less competitive races remain virtually unchanged.

The anxieties mechanism can also be demonstrated by comparing how perceived discrimination varies between plurality groups and minorities as competitive elections approach. The rejection-dis-identification model of ethnic identification predicts that minority groups in particular will reject common identities in response to

\footnotetext{
${ }^{15}$ Generalized trust coded 1 if respondents answered "Most people can be trusted", 0 if "You must be very careful" to "Generally speaking, would you say that most people can be trusted or that you must be very careful in dealing with people?".
} 


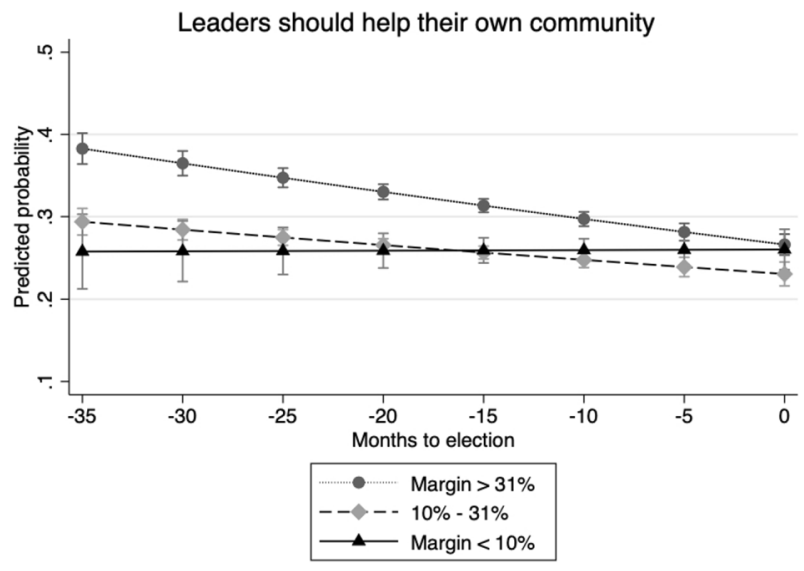

Fig. 7 Competitive elections and support for co-ethnic favoritism. Note Predicted probabilities with 95intervals. All covariates held at their means. Detailed results and additional specifications in the Online Appendix

discrimination and unfair treatment, so we should expect to see greater divergence in levels of perceived discrimination between minority and majority/plurality groups when the anxieties mechanism is in play. Group size is also plausibly exogenous to the electoral cycle and the competitiveness of the election.

Figure 5, right panel, shows that minority groups are more likely to perceive ethnically-based discrimination close to competitive elections, while levels of perceived discrimination for plurality groups actually slightly decrease. This suggests that the increase of ethnic identification close to competitive elections in Africa is largely driven by aggrieved minority groups rejecting national identities in response to perceived discrimination. Comparing perceived discrimination by ethnic group size and electoral competitiveness (left, middle, and right panel of Fig. 5) also points to a much higher level of ethnic polarization close to competitive elections in particular, which is not evident for elections with winning margins $>10 \%$.

Do anxieties result from the polarized campaign environment that likely precedes competitive elections or could they be due to other factors, such as disputed results or (fears of) electoral violence? While the current data does not allow me to fully disentangle these potential explanations, it is instructive to examine how perceived discrimination varies by levels of rally attendance. Rallies are the primary means of campaign communication in Sub-Saharan Africa (Paget 2019) so rally attendance is a reasonable proxy for campaign exposure.

Figure 6 shows that respondents who attended rallies are more likely to perceive ethnic discrimination close to competitive elections, while rally attendance does not correlate with perceived discrimination close to landslides. This is suggestive evidence pointing to the presence of campaign effects influencing perceived discrimination, and thus ethnic identification, close to competitive elections in Africa. Respondents interested in public affairs are also more likely to report ethnic discrimination as competitive elections approach compared to those who express no such interest (in the Online Appendix). Finally, in the Online Appendix I also explicitly control for the effect of 
contested elections on respondents' national identification and perceived discrimination (Appendix Tables S5 and S6), which does not change the main findings. Together, Figs. 2, 3, 4, 5 and 6 provide strong evidence of a general increase in group anxieties close to competitive elections in Sub-Saharan Africa.

\section{Political Competition and Support for Ethnic Favoritism}

In this section, I examine the effects of political competition on individual attitudes towards ethnic favoritism as captured in responses to the Afrobarometer question asking whether leaders should benefit all or help their own communities once in power. There is some evidence that acceptance of ethnic favoritism also grows as competitive elections draw near (Fig. 7). The proximity and competitiveness variables and their interaction are significant and robust to the inclusion of individual covariates and social desirability controls.

Figure 7 shows a very slight increase in perceptions that leaders should benefit their own communities for competitive elections, but the significance of the interaction term is driven by the relatively larger decrease of the acceptability of ethnic favoritism closer to landslide elections. One way to interpret these findings is to consider that because the results in landslide elections are known well in advance, there is little doubt about which ethnic groups would be privileged once returned to power (often presidents' coethnics and their closest allies). Given the high levels of ethnic diversity in Sub-Saharan Africa (Fearon 2003), the majority of Afrobarometer respondents are not likely to be among the lucky few. In this case, it would make sense that respondents should oppose ethnic favoritism by entrenched incumbents.

The results may also be capturing changes in voters' normative attitudes towards patronage, rather than intrinsic support for the practice as such. Or, voter outreach and education efforts related to the campaigns may result in individuals viewing ethnic favoritism by politicians more negatively as the election date nears. Recent research has drawn attention to increased political knowledge resulting from electoral campaigns in Africa's competitive authoritarianisms (Conroy-Krutz 2016). The nature of the question and data do not allow me to distinguish between these mechanisms, which may also be operating in tandem. While the evidence presented here is suggestive, other methods may be more suitable for capturing intrinsic attitudes towards ethnic favoritism in Sub-Saharan Africa and how these vary in relation to the proximity and competitiveness of elections (Kramon 2011).

\section{Discussion}

While the paper's findings regarding the effect of political competition on respondents' patronage attitudes are ambivalent, political competition clearly increases ethnic anxieties in Sub-Saharan Africa. For three distinct literatures-on ethnic boundary-making, relative deprivation, and on the link between rejection and disidentification, the relationship between group anxieties and increased ethnic identification is causal. 
Increased ethnic anxieties around election times in Africa are reasons for concern. Research has shown that perceived discrimination heightens inter-group differentiation (Cronin et al. 2011), promotes activism and protest (Gurr 1993), reduces cooperation (Jasinskaja-Lahti et al. 2009), and is associated with the rejection of democracy and democratic institutions overall (Maxwell 2014). Many studies have documented a rise in election-related incidents and violence in Africa since the reintroduction of multi-party elections in the 1990s and political contests have been described as "do or die affairs" (Bratton 2008; De Smedt 2009).

It is important to note that these findings should not be interpreted as evidence against the benefits of competitive elections. In fact, all anxiety indicators are higher for non-competitive elections. ${ }^{16}$ This means that where competition is high, ethnic anxieties and levels of inter-ethnic trust fluctuate in relation to the electoral cycle. In light of these findings, political competition should be welcomed and encouraged, but policies and institutions designed to ensure fairness and alleviate ethnic tensions closer to elections will be crucial to successful democratization in Africa as elections become more competitive.

A number of limitations exist regarding the generalizability of the results, remaining response bias related to the attitudinal measures used in the paper, and the potential for omitted variable bias. The seventeen countries included in the sample may not be representative of African countries overall. The Afrobarometer only collects data on countries where there is no civil conflict, and which have a nominal level of democracy so the results generalize accordingly. Nevertheless, given the theoretical interest in the effect of the electoral environment on individual identification, a sample of countries holding regular elections with varying levels of competitiveness is appropriate. Despite various measures taken to address response bias in Afrobarometer interview data, it does remain a concern given the sensitive nature of the questions. Yet, the fact that all affective variables exhibit significant movement in one direction in response to the political environment and in accordance with theory from several disciplines, which is also in line with case study research, increases confidence in the results.

Finally, could the same factors driving the rise of competitiveness in Sub-Saharan Africa also increase ethnic anxieties? The literature suggests several drivers of competitiveness on the continent: financial liberalization, increased voter education and sophistication as a result of ongoing modernization and urbanization, and higher party institutionalization. These are all relatively slowly unfolding processes unlikely to change on a monthly basis. Given the findings regarding the effects of the survey timing on national identification (the former being exogenous to competitiveness), the nested data structure and fixed effects framework adopted in the paper should account for such potential national-level confounders.

\footnotetext{
16 The perceived discrimination mean is 0.69 for competitive elections compared to 0.62 for less-competitive ones and 0.71 for landslides; the economic anxiety mean is 1.108 for competitive elections, 1.129 for less competitive ones and 1.113 for landslides; the political anxiety mean is 1.048 for competitive elections, 1.230 for less competitive ones and 1.063 for landslides; the ethnic trust mean is 1.94 for competitive elections, 1.57 for less competitive ones, and 1.74 for landslides.
} 
Because I am interested in how the electoral cycle interacts with the competitiveness of national-level elections to impact individual attitudes and perceptions, the framework adopted in this paper does not capture sub-national factors, which could vary within survey rounds over time and also influence citizens' attitudes and identities. These include differences in competitiveness levels locally, regional protests or violence, cultural events (eg. traditional festivals or commemorative events), and other regional economic, political or environmental factors. While undoubtedly important, if the rise in ethnic anxieties close to competitive elections in Africa was largely due to local factors, it would have been difficult to obtain statistically significant results for national-level variables. Nevertheless, this is a fruitful area for future research.

\section{Conclusion}

This paper provides the first cross-national empirical test of the effects of political competition on ethnic groups' status anxieties and presents strong evidence that these anxieties peak close to competitive elections. While the empirical focus is on Sub-Saharan Africa, the findings are relevant to plural democracies more broadly. A key take-away is that group anxieties and ethnic grievances rise and fall with electoral cycles. Understanding and addressing this cyclical variation is crucial for the success of both democracy and nation-building in multi-ethnic states.

The paper also shows that political competition reduces national relative to ethnic identification in Sub-Saharan Africa. This result is important because the relative salience of ethnic versus national identity is an indirect measure of ethnocentrism, which has been blamed for a number of ills throughout the world. Two potential mechanisms can account for this shift: instrumental motivations and ethnic anxieties. Of the two, I find stronger evidence for the presence of the anxieties mechanism. This is in line with theories from social psychology positing that ethnic identification is undertaken in response to perceived discrimination and relative status concerns. Although the increase of ethnic anxieties around competitive elections in Africa appears to be affective in nature, this does not imply instrumental motivations do not play a part. Fears of loss of status and the desire to seek refuge in group belonging are perfectly rational responses to perceived threat and discrimination. Thus, the two mechanisms likely operate in tandem and instrumental motivations are expressed through affective responses, in survey responses in particular. Future research should strive to better integrate the instrumental and affective aspects of group identities and the types of responses different survey measures invite.

Finally, in light of findings regarding the importance of local ethnic geography for levels of intra-ethnic tolerance (Kasara 2013) and the varying levels of competitiveness among core and swing regions within the same state (Horowitz 2015), future research can study sub-national variation in the effect of proximity to competitive elections on ethnic identification and group anxieties. Given the well-established link between ethnic anxieties, (violent) protests, and the rejection 
of common institutions, understanding such sub-national variation would be key to identifying likely hotspots and devising targeted solutions able to mitigate the divisiveness of rising electoral competitiveness in Africa's highly diverse states.

Supplementary Information The online version of this article (https://doi.org/10.1007/s11109-02109684-z) contains supplementary material, which is available to authorized users.

Acknowledgements I would like to thank Madhavi Devasher, Michalis Moutselos, and Shana Warren for comments on earlier versions of this paper and three anonymous reviewers for immensely constructive feedback. I am also grateful to Hannah Vester for research help and for funding provided by the Princeton Institute for International and Regional Studies and the Max Planck Institute for the Study of Religious and Ethnic Diversity.

Open Access This article is licensed under a Creative Commons Attribution 4.0 International License, which permits use, sharing, adaptation, distribution and reproduction in any medium or format, as long as you give appropriate credit to the original author(s) and the source, provide a link to the Creative Commons licence, and indicate if changes were made. The images or other third party material in this article are included in the article's Creative Commons licence, unless indicated otherwise in a credit line to the material. If material is not included in the article's Creative Commons licence and your intended use is not permitted by statutory regulation or exceeds the permitted use, you will need to obtain permission directly from the copyright holder. To view a copy of this licence, visit http://creativecommons.org/licen ses/by/4.0/.

\section{References}

Aspinall, E. (2007). The construction of grievance natural resources and identity in a separatist conflict. Journal of Conflict Resolution, 51(6), 950-972.

Barreto, M. A., \& Pedraza, F. I. (2009). The renewal and persistence of group identification in American politics. Electoral Studies, 28(4), 595-605.

Barth, F. (1998). Ethnic groups and boundaries: The social organization of culture difference. Waveland Press.

Bates, R. H. (1983). Modernization, ethnic competition, and the rationality of politics in contemporary africa. State Versus Ethnic Claims, 152, 171.

Bhavnani, R., \& Miodownik, D. (2009). Ethnic polarization, ethnic salience, and civil war. Journal of Conflict Resolution, 53(1), 30-49.

Blumer, H. (1958). Race prejudice as a sense of group position. Pacific Sociological Review, 1, 3-7.

Bogardus, E. S. (1928). Immigration and race attitudes.

Boone, C. (2011). Politically allocated land rights and the geography of electoral violence: The case of kenya in the 1990s. Comparative Political Studies, 0010414011407465.

Bossuroy, T. (2008). Ethnicity as a resource in social capital. Paris School of Economics, DIAL: Typescript.

Bratton, M. (2008). Vote buying and violence in nigerian election campaigns. Electoral Studies, 27(4), $621-632$.

Brewer, M. B. (1981). Ethnocentrism and its role in interpersonal trust. Scientific Inquiry and the Social Sciences, 214, 231.

Burbidge, D. (2014). 'can someone get me outta this middle class zone?!'ressures on middle class kikuyu in Kenya's 2013 election. The Journal of Modern African Studies, 52(02), 205-225.

Carlson, E. (2015). Ethnic voting and accountability in Africa: A choice experiment in Uganda. World Politics, 67, 353.

Cederman, L.-E., Gleditsch, K. S., \& Hug, S. (2013). Elections and ethnic civil war. Comparative Political Studies, 46(3), 387-417.

Cederman, L.-E., Wimmer, A., \& Min, B. (2010). Why do ethnic groups rebel? New data and analysis. World Politics, 62(1), 87-119. 
Chandra, K. (2007). Why ethnic parties succeed: Patronage and ethnic head counts in India. Cambridge: Cambridge University Press.

Chandra, K. (2012). Constructivist theories of ethnic politics. Oxford: Oxford University Press.

Collier, P. (2011). Wars, guns and votes: Democracy in dangerous places. New York: Random House. Random House.

Conroy-Krutz, J. (2016). Electoral campaigns as learning opportunities: Lessons from Uganda. African Affairs.

Conroy-Krutz, J., Moehler, D. C., \& Aguilar, R. (2016). Partisan cues and vote choice in new multiparty systems. Comparative Political Studies, 49(1), 3-35.

Cronin, T. J., S. Levin, N. R. Branscombe, C. van Laar, and L. R. Tropp (2011). Ethnic identification in response to perceived discrimination protects well-being and promotes activism: A longitudinal study of latino college students. Group Processes \& Intergroup Relations, 1368430211427171.

Curini, L., Jou, W., \& Memoli, V. (2012). Satisfaction with democracy and the winner/loser debate: The role of policy preferences and past experience. British Journal of Political Science, 42(2), 241-261.

De Smedt, J. (2009). 'No raila, no peace!'big man politics and election violence at the Kibera grassroots. African Affairs, 108(433), 581-598.

Easterly, W., \& Levine, R. (1997). Africa's growth tragedy: Policies and ethnic divisions. The Quarterly Journal of Economics, 112(4), 1203-1250.

Easterly, W., Ritzen, J., \& Woolcock, M. (2006). Social cohesion, institutions, and growth. Economics \& Politics, 18(2), 103-120.

Eifert, B., Miguel, E., \& Posner, D. N. (2010). Political competition and ethnic identification in Africa. American Journal of Political Science, 54(2), 494-510.

Fearon, J. D. (1999). Why ethnic politics and 'pork' tend to go together. In an SSRC-MacArthur sponsored conference on "Ethnic Politics and Democratic Stability," University of Chicago.

Fearon, J. D. (2003). Ethnic and cultural diversity by country. Journal of Economic Growth, 8(2), 195-222.

Ferree, K. E. (2006). Explaining south Africa's racial census. The Journal of Politics, 68(4), 803-815.

Ferree, K. E. (2010). Framing the race in South Africa: The political origins of racial census elections. Cambridge: Cambridge University Press.

Franklin, M. N., et al. (2004). Voter turnout and the dynamics of electoral competition in established democracies since 1945. Cambridge: Cambridge University Press.

Gadjanova, E. (2013). What is an ethnic appeal? Policies as metonymies for ethnicity in the political rhetoric of group identity. Ethnopolitics, 12(3), 307-330.

Gadjanova, E. (2017). Electoral clientelism as status affirmation in Africa: evidence from Ghana. The Journal of Modern African Studies, 55(4), 593-621.

Gelman, A., \& Hill, J. (2006). Data analysis using regression and multilevel/hierarchical models. Cambridge: Cambridge University Press.

Giebler, H., S. Banducci, \& S. Kritzinger (2017). New perspectives on information and electoral competition.

Gurr, T. R. (1993). Why minorities rebel: A global analysis of communal mobilization and conflict since 1945. International Political Science Review, 14(2), 161-201.

Habyarimana, J., Humphreys, M., Posner, D. N., \& Weinstein, J. M. (2009). Coethnicity: Diversity and the dilemmas of collective action. New York: Russell Sage Foundation.

Hale, H. (2008). The foundations of ethnic politics: Separatism of states and nations in Eurasia and the world. Cambridge: Cambridge University Press.

Hansen, K. M., \& Kosiara-Pedersen, K. (2017). How campaigns polarize the electorate: Political polarization as an effect of the minimal effect theory within a multi-party system. Party Politics, 23(3), 181-192.

Harrington, J. E, Jr., \& Hess, G. D. (1996). A spatial theory of positive and negative campaigning. Games and Economic behavior, 17(2), 209-229.

Herbst, J. (1989). The creation and matintenance of national boundaries in Africa. International Organization, 43(04), 673-692.

Higashijima, M., \& Houle, C. (2018). Ethnic inequality and the strength of ethnic identities in sub-saharan Africa. Political Behavior, 40(4), 909-932.

Horowitz, D. L. (1985). Ethnic groups in conflict. Berkeley: Univ of California Press.

Horowitz, J. (2015). The ethnic logic of campaign strategy in diverse societies: Theory and evidence from kenya. Comparative Political Studies. 
Ichino, N., \& Nathan, N. L. (2013). Crossing the line: Local ethnic geography and voting in Ghana. American Political Science Review, 107(02), 344-361.

Iyengar, S., Sood, G., \& Lelkes, Y. (2012). Affect, not ideology a social identity perspective on polarization. Public Opinion Quarterly, 76(3), 405-431.

Jasinskaja-Lahti, I., Liebkind, K., \& Solheim, E. (2009). To identify or not to identify? National disidentification as an alternative reaction to perceived ethnic discrimination. Applied Psychology, 58(1), $105-128$.

Kasara, K. (2013). Separate and suspicious: Local social and political context and ethnic tolerance in Kenya. The Journal of Politics, 75(04), 921-936.

Kramon, E. (2011). Why do politicians buy votes when the ballot is secret? Theory and experimental evidence from Kenya. Stanford: Working Group on African Political Economy.

Kuo, A., \& Margalit, Y. (2012). Measuring individual identity: Experimental evidence. Comparative Politics, 44(4), 459-479.

LeVine, R. A., \& Campbell, D. T. (1972). Ethnocentrism: Theories of conflict, ethnic attitudes, and group behavior. New York: Wiley.

Maxwell, R. (2009). Caribbean and south Asian identification with British society: The importance of perceived discrimination. Ethnic and Racial Studies, 32(8), 1449-1469.

Maxwell, R. (2014). Perceived discrimination across institutional fields: Racial minorities in the united kingdom. European Sociological Review, jcu094.

McCulloch, C. E. and J. M. Neuhaus (2005). Generalized linear mixed models. Encyclopedia of biostatistics 4.

Michelitch, K. (2015). Does electoral competition exacerbate interethnic or interpartisan economic discrimination? Evidence from a field experiment in market price bargaining. American Political Science Review, 109(1), 43-61.

Miguel, E., \& Posner, D. N. (2006). Sources of ethnic identification in Africa. Berkeley: University of California.

Moehler, D. C. (2009). Critical citizens and submissive subjects: Election losers and winners in africa. British Journal of Political Science, 39(2), 345-366.

Nugent, P. (2001). Winners, losers and also rans: Money, moral authority and voting patterns in the Ghana 2000 election. African Affairs, 100(400), 405-428.

Paget, D. (2019). The rally-intensive campaign: A distinct form of electioneering in sub-saharan Africa and beyond. The International Journal of Press/Politics, 24(4), 444-464.

Peterson, R. D. (2002). Understanding ethnic violence. New York: Cambridge University.

Posner, D. N. (2005). Institutions and ethnic politics in Africa. New York: Cambridge University Press.

Posner, D. N., \& Young, D. J. (2007). The institutionalization of political power in Africa. Journal of Democracy, 18(3), 126-140.

Rabe-Hesketh, S. and A. Skrondal (2008). Multilevel and longitudinal modeling using Stata. STATA press.

Robinson, A. L. (2014). National versus ethnic identification in Africa: Modernization, colonial legacy, and the origins of territorial nationalism. World Politics, 66(04), 709-746.

Sambanis, N. (2001). Do ethnic and nonethnic civil wars have the same causes? A theoretical and empirical inquiry (part 1). Journal of Conflict Resolution, 45(3), 259-282.

Sherif, M., O. Harvey, B. J. White, W. R. Hood, and C. W. Sherif (1961). Intergroup cooperation and competition: The robbers cave experiment.

Skaperdas, S., \& Grofman, B. (1995). Modeling negative campaigning. American Political Science Review, 89(1), 49-61.

Tajfel, H. (1982). Social psychology of intergroup relations. Annual Review of Psychology, 33(1), 1-39.

Trumm, S., Sudulich, L., \& Townsley, J. (2017). Information effect on voter turnout: How campaign spending mobilises voters. Acta Politica, 52(4), 461-478.

Varshney, A. (2003). Nationalism, ethnic conflict, and rationality. Perspectives on Politics, 85-99.

Weber, M. (1978). Economy and society. Berkeley.

Weghorst, K. R., \& Lindberg, S. I. (2013). What drives the swing voter in Africa? American Journal of Political Science, 57(3), 717-734.

Wilkinson, S. (2005). Religious Politics and Communal Violence. Oxford: Oxford University Press.

Wimmer, A. (1997). Who owns the state? Understanding ethnic conflict in post-colonial societies. Nations and Nationalism, 3(4), 631-666.

Wimmer, A. (2008). The making and unmaking of ethnic boundaries: A multilevel process theory. American Journal of Sociology, 113(4), 970-1022. 
Wimmer, A. (2013). Ethnic boundary making: Institutions, power, networks. Oxford: Oxford University Press.

Wooldridge, J. M. (2016). Introductory econometrics: A modern approach. Nelson Education. Young, C. (1979). The politics of cultural pluralism. Madison: Univ of Wisconsin Press.

Publisher's Note Springer Nature remains neutral with regard to jurisdictional claims in published maps and institutional affiliations. 